SANDRI, M.A.; ANDRIOLO, J.L.; WITTER, M; DAL ROSS, T. Effect of shading on tomato plants grow under greenhouse. Horticultura Brasileira, Brasília, v. 21, n. 4, p. 642-645, outubro-dezembro 2003.

\title{
Effect of shading on tomato plants grow under greenhouse ${ }^{1}$
}

\author{
Miguel Angelo Sandri ${ }^{2}$; Jerônimo Luiz Andriolo ${ }^{3}$; Marcio Witter ${ }^{4}$; Tiago Dal Ross ${ }^{4}$ \\ ${ }^{2}$ CEFET, Via do Conhecimento, km 01, Bom Retiro, 85503-390 Pato Branco-PR; ${ }^{3}$ UFSM-CCR-Depto. de Fitotecnia, 97105-900, Santa \\ Maria-RS. E-mail: andriolo@creta.ccr.ufsm.br; ${ }^{4}$ Bolsista de iniciação científica
}

\begin{abstract}
The experiment was conducted at Universidade Federal de Santa Maria, Rio Grande do Sul State, Brazil, to determine the effect of shading on tomato plants grown in a greenhouse. Sowing was done on July $4^{\text {th }}$ and planting on August $27^{\text {th }}, 2000$, in a plant density of 3.3 plants $\mathrm{m}^{-2}$, using an organic commercial rooting medium. Water and nutrients were supplied on a daily basis using a nutrient solution. Two polyethylene tunnels ( $2.20 \mathrm{~m}$ height, $5 \mathrm{~m}$ width, $15 \mathrm{~m}$ length) were used. In the first plastic tunnel, used as control, the transmissivity of global radiation was $83 \%$ and plants were conducted as a commercial crop. In the second tunnel, plants were grown under a $52 \%$ shading screen. Plant growth and development were measured at $19 ; 26 ; 33 ; 40 ; 47 ; 54 ; 61 ; 75$ and 89 days after beginning of anthesis. Daily average solar radiation in the first tunnel from planting time to the end of the experiment was $12.4 \mathrm{MJ} \mathrm{m}^{-2}$ day $^{-1}$, whereas in the shaded tunnel it was $5.0 \mathrm{MJ} \mathrm{m}^{-2} \mathrm{day}^{-1}$. Number of fruits per square meter did not differ significantly between the unshaded control and shaded tomato plants. At the last harvest, dry mass from unshaded and shaded plants differed significantly, with values of $974.9 \mathrm{~g} \mathrm{~m}^{-2}$ and $762.5 \mathrm{~g} \mathrm{~m}^{-2}$ for total dry mass, $550.1 \mathrm{~g} \mathrm{~m}^{-2}$ and $419.74 \mathrm{~g} \mathrm{~m}^{-2}$ for fruits, and $424.75 \mathrm{~g} \mathrm{~m}^{-2}$ and $342.74 \mathrm{~g} \mathrm{~m}^{-2}$ for vegetative organs, respectively. Total plant growth was reduced to $21.7 \%$ by shading, but plants continued to grow, in spite of the radiation level below the trophic limit of $8.4 \mathrm{MJ} \mathrm{m}^{-2} \mathrm{day}^{-1}$. To establish the climatic suitability of horticultural crops in different regions, it should be advisable to take in account other variables than solar radiation.
\end{abstract}

Keywords: Lycopersicon esculentum, growth efficiency, solar radiation, climatic suitability.

\section{RESUMO}

Efeito do sombreamento sobre o crescimento do tomateiro em cultivo protegido

O experimento foi conduzido na Universidade Federal de Santa Maria, para determinar o efeito do sombreamento sobre o crescimento do tomateiro em cultivo protegido. A semeadura foi feita em 04/07/00 e o plantio em 27/08, na densidade de 3,3 plantas $\mathrm{m}^{-2}$, empregando substrato comercial orgânico. A água e os nutrientes foram fornecidos diariamente através de uma solução nutritiva. Dois túneis de polietileno $(2,20 \mathrm{~m}$ de altura, $5 \mathrm{~m}$ de largura e $15 \mathrm{~m}$ de comprimento) foram empregados. Em um dos túneis, a transmissividade da radiação solar global foi de $83 \%$ e plantas testemunha foram cultivadas, empregando-se o mesmo manejo praticado na produção comercial dessa cultura. Plantas sombreadas foram cultivadas no segundo túnel, onde por ocasião da antese da primeira inflorescência foi instalada uma tela com $52 \%$ de sombreamento, logo abaixo do filme de polietileno de cobertura do túnel. O crescimento e o desenvolvimento foram determinados aos $19 ; 26 ; 33 ; 40$; 47; 54; 61; 75 e 89 dias após o início da antese. A média diária de radiação solar global dentro do túnel testemunha, no período entre o plantio e o final do experimento foi de $12,4 \mathrm{MJ} \mathrm{m}^{-2} \mathrm{dia}^{-1}$, enquanto no túnel sombreado, após a instalação da tela de sombreamento, foi de 5,0 $\mathrm{MJ} \mathrm{m}^{-2} \mathrm{dia}^{-1}$. O número de frutos por unidade de área de solo não diferiu significativamente entre as plantas testemunha e sombreadas. Na última coleta a massa seca das plantas testemunha e sombreadas diferiu significativamente e os valores foram, respectivamente, $974,9 \mathrm{~g} \mathrm{~m}^{-2}$ e $762,5 \mathrm{~g} \mathrm{~m}^{-2}$ para a massa seca total, $550,1 \mathrm{~g}$ $\mathrm{m}^{-2}$ e $419,74 \mathrm{~g} \mathrm{~m}^{-2}$ para os frutos e 424,75 $\mathrm{g} \mathrm{m}^{-2}$ e $342,74 \mathrm{~g} \mathrm{~m}^{-2}$ para os órgãos vegetativos. A massa seca total foi reduzida em $21,7 \%$ pelo sombreamento, porém as plantas continuaram a crescer, apesar do nível de radiação inferior ao limite trófico de $8,4 \mathrm{MJ} \mathrm{m}^{-2} \mathrm{dia}^{-1}$. Para determinar a disponibilidade climática de hortaliças em diferentes regiões é recomendável levar em consideração também outras variáveis climáticas além da radiação solar.

Palavras-chave: Lycopersicon esculentum, eficiência de crescimento, radiação solar, disponibilidade climática.

\section{(Recebido para publicação em 9 de setembro de 2002 e aceito em 13 de agosto de 2003)}

$\mathrm{O}$ ne of the major goals of vegetable crop production around the world is the ability to produce throughout the year. To accomplish this objective, climatic variables such as air and soil temperatures, and also $\mathrm{CO}_{2}$ air concentration must be artificially controlled. As production costs increase by using these practices, growing areas in protected cultivation are trending towards mild climatic regions of the world, where plants can grow without artificial control of the environment. It is so in Southern Brazil, where tomato crop production in greenhouses is done in autumn and spring.
Growth and yield of crops are related to the amount of solar radiation received during the growing period (Cockshull et al., 1992; Challa \& Bakker, 1998). For the tomato crop, a theoretical light use efficiency of $1.0 \mathrm{~g}$ dry mass $\mathrm{MJ}^{-1}$ of global radiation outside the greenhouse was calculated, which equals $3.1 \mathrm{~g}$ dry

\footnotetext{
${ }^{1}$ Parte da dissertação de tese do programa de pós-graduação em agronomia da UFSM.
} 
mass $\mathrm{MJ}^{-1}$ of photosynthetically active radiation (PAR) inside the greenhouse (Challa \& Bakker, 1998). The lowest limit of solar radiation below which summer horticultural crops can not survive, defined as the trophic limit, has been established as $8.4 \mathrm{MJ} \mathrm{m}^{-2}$ day $^{-1}$ (FAO, 1990). This trophic limit was confirmed in Southern Brazil, where winter tomato crops showed losses on plant dry mass when radiation fell to values below this limit (Andriolo et al., 1998). Based on this concept, solar radiation levels during the year have been used as a key variable to find out regions or seasons suitable for horticultural summer crops (Estefanel et al., 1998; Buriol et al., 2000). On the other hand, in the literature there is a reduced amount of data showing the upper limit of solar radiation above which production of these crops is reduced. In fact, in summer conditions, climatic restrictions to plant growth have been attributed mainly to the effects of high temperatures on photosynthesis and respiration (Lapuerta, 1995; CTFIL, 1995). It is not clear if solar radiation could be used alone to estimate the performance of crops, or interactions with other climatic variables, specially air temperature, must also be considered. Although air temperatures are related to solar radiation, this relationship is not constant, and may show variations in different seasons and/or locations.

In this work the growth and yield of tomato plants, grown during the spring season under different values of solar radiation was investigated. During this period, the limiting effects of low air temperatures on crop growth were not expected. The light use efficiency was also calculated and relations with climatic requirements for horticultural crops were discussed.

\section{MATERIAL AND METHODS}

The experiment was carried out at the Universidade Federal de Santa Maria, Rio Grande do Sul State, Brazil, in 2000. The indeterminate tomato hybrid Monte Carlo was grown inside two polyethylene tunnels (2.20 m height, $5 \mathrm{~m}$ width, $15 \mathrm{~m}$ length). Sowing was done in polystyrene

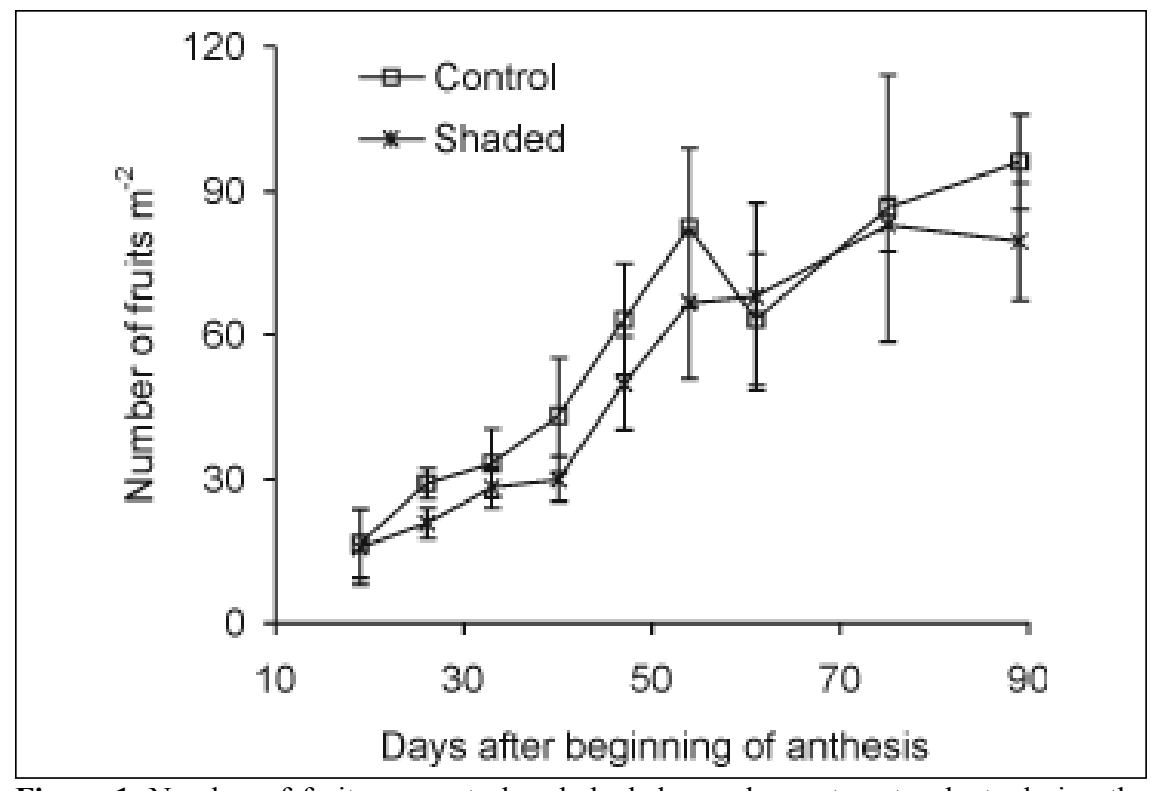

Figure 1. Number of fruits on control and shaded greenhouse tomato plants during the growing period. Santa Maria, UFSM, 2000.

trays filled with a commercial rooting medium at July $4^{\text {th }}$, and planting at August $27^{\text {th }}$. Plants were grown in bags containing $5.5 \mathrm{~L}$ of a commercial substrate, and spaced $1.0 \mathrm{~m}$ between rows and $0.3 \mathrm{~m}$ between bags in the row. Plants were trained in the high-wire system, with one stem per plant. Water and nutrients were supplied daily to plants by means of a nutrient solution, in order to replace water lost by transpiration, with a drainage coefficient of about $25 \%$. The nutrient solution used was the one used to grow tomatoes in hydroponics (CTIFL, 1995), with the following quantities of fertilizers, in mmol. $\mathrm{L}^{-1}$ : $\mathrm{KNO}_{3}, 4.0 ; \mathrm{K}_{2} \mathrm{SO}_{4}, 0.9 ; \mathrm{Ca}\left(\mathrm{NO}_{3}\right)_{2}, 3.75$; $\mathrm{KH}_{2} \mathrm{PO}_{4}, 1.5 ; \mathrm{MgSO}_{4}, 1,0$; iron chelate $19 \times 10^{-3}$. Microelements were added by a standard mixture. Ventilation of tunnels was done on sunny days, by lifting tunnel sides, to reduce air humidity.

In the tunnel used as control, plants were conducted in the same way as for a commercial production. The polyethylene film covering the tunnel reduced the transmissivity of solar radiation to $83 \%$. In the second tunnel, at anthesis of the first truss (September, $\left.21^{\text {th }}\right)$ a $52 \%$ shading screen was installed just below the polyethylene film, to reduce transmissivity to $40 \%$, in relation to outside global radiation. In both tunnels, four plants were randomly selected and harvested at $19 ; 26 ; 33 ; 40$;
$47 ; 54 ; 61 ; 75$ and 89 days after the beginning of anthesis (DAA). After harvest, the number of fruits ( $>$ than 1 $\mathrm{cm}$ diameter) was recorded. Dry mass of vegetative organs (leaves and stem, including petioles and peduncles) and fruits were measured after drying at $60^{\circ} \mathrm{C}$ for one week. Specific leaf area (SLA) was measured based on dry mass of disk leaf samples $\left(0.5 \mathrm{~cm}^{2}\right.$ area $)$. Leaf area index (LAI) was estimated by extrapolating the SLA to the total dry mass of leaves. For SLA and LAI determinations, the first leaf below each truss was chosen and considered representative of the sympode. All leaflets wider than $0.01 \mathrm{~m}$ of selected leaves were sampled and values were pooled together to calculate the average value of the plant. For statistical purposes, an entirely randomised experimental design was considered in each tunnel, and the $t$ Test was used to discriminate the treatment means. Data from temperature and sunshine were recorded by the Climatological Station, located $100 \mathrm{~m}$ far from the experimental area. Daily maxima and minima average temperatures were recorded and solar radiation was estimated by the Ångstron's model, with coefficients adjusted for Santa Maria by Estefanel et al. (1990). The absorption of radiation by the crop at each harvest was estimated by the Lambert-Beer law with 


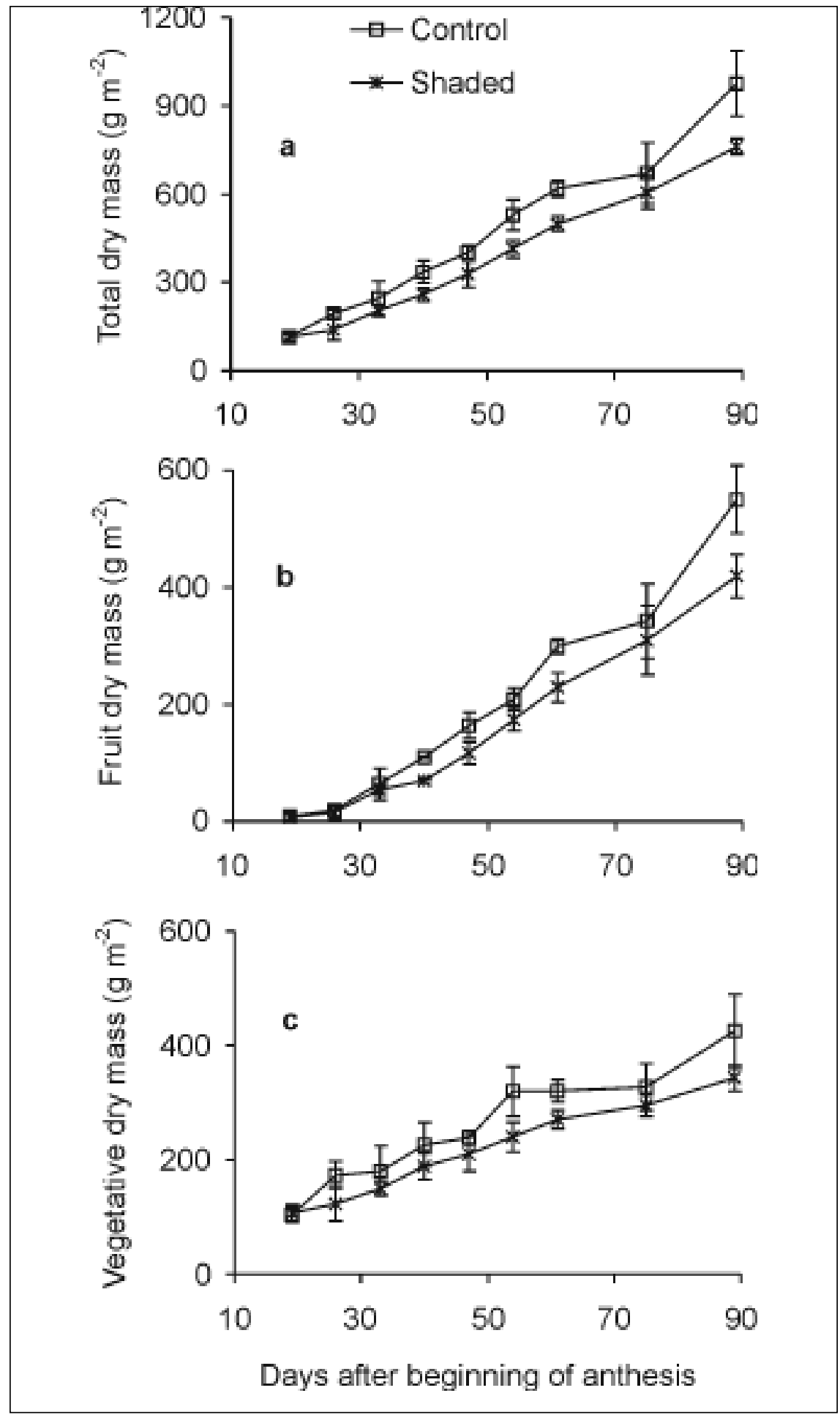

Figure 2. Total (a), fruit (b) and vegetative (c) dry mass on control and shaded greenhouse tomato plants during the growing period. Santa Maria, UFSM, 2000.

a $k$ value of 0.70 (Bertin, 1993).

\section{RESULTS AND DISCUSSION}

Daily average solar radiation inside the unshaded tunnel, measured from planting to the end of the experiment was $12.4 \mathrm{MJ}$ cumulated solar radiation was $427.7 \mathrm{MJ}$ $\mathrm{m}^{-2}$ until the end of the experiment. Mean daily outside air temperatures increased from $15^{\circ} \mathrm{C}$ at onset to $26^{\circ} \mathrm{C}$ at the end of the experiment, and average value was $19.7^{\circ} \mathrm{C}$.

Number of fruits per square meter did not differ significantly between control and shaded plants (Figure 1). At the last harvest, values were 96.02 fruits $\mathrm{m}^{-2}$ and 79.36 fruits $\mathrm{m}^{-2}$, respectively. Dry mass of vegetative organs increased during the experiment, with higher values on control plants. At the last harvest, dry mass on control and shaded plants differed significantly, and values were, respectively, $974.9 \mathrm{~g} \mathrm{~m}^{-2}$ and $762.5 \mathrm{~g} \mathrm{~m}^{-2}$ for total dry mass (Figure 2a), $550.1 \mathrm{~g} \mathrm{~m}^{-2}$ and $419.74 \mathrm{~g} \mathrm{~m}^{-2}$ for fruits (Figure $2 \mathrm{~b}$ ), and $424.75 \mathrm{~g} \mathrm{~m}^{-2}$ and $342.74 \mathrm{~g} \mathrm{~m}^{-2}$ for vegetative organs (Figure 2c). Differences in leaf area index (LAI) between control and shaded plants increased at successive harvests (Figure 3a). Final values were $4.70 \mathrm{~m}^{2} \mathrm{~m}^{-2}$ and $3.94 \mathrm{~m}^{2} \mathrm{~m}^{-2}$, respectively, which differed significantly $(\mathrm{p}<0.05)$. Specific leaf area (SLA) decreased after 47 DAA (Figure $3 \mathrm{~b}$ ), and final values were $233.43 \mathrm{~cm}^{2} \mathrm{~g}^{-1}$ and $320.60 \mathrm{~cm}^{2} \mathrm{~g}^{-1}$ on control and shaded plants, respectively.

Data presented in this paper confirms the relationship between fruit yield and cumulated solar radiation, that has been previously demonstrated for tomato crops (Cockshull et al., 1992). The light use efficiency (LUE) of control plants was $2.37 \mathrm{~g}$ dry mass $\mathrm{MJ}^{-1}$ of PAR. This value is near that reported by Heuvelink (1996), of $2.5 \mathrm{~g}_{\text {dry mass }} \mathrm{MJ}^{-1}$ of PAR, averaged over 12 growth experiments in the Netherlands. Nevertheless, it is lower than the value of $3.1 \mathrm{~g}$ dry mass $\mathrm{MJ}^{-1}$ of Photosynthetically Active Radiation (PAR) calculated by Challa \& Baker (1998) as the theoretical potential crop growth rate for a greenhouse tomato crop. This result may be attributed to the duration of the growing period and also to light intensity. From early stages of development until harvest of first fruits, the LAI of the crop increased, but partitioning of plant dry mass between fruits and vegetative organs favouring fruits. It was demonstrated that at later stages of tomato plant development, growth of vegetative organs suffers from competition of fruits. As a consequence, the fraction of dry matter allocated to fruits reaches its maximum (Koning, 1994; 
Heuvelink, 1996). In the present experiment, the growing period was 114 days, shorter than that of northern hemisphere tomato crops, about nine months (Cockshull et al., 1992). In this situation, a fraction of the incident solar radiation at early stages of crop development may be lost, due to low LAI. On the other hand, daily levels of solar radiation increased from the onset to the end of the experiment and may have been excessive at later stages of crop development, decreasing rates of photosynthesis and dry mass accumulation.

In shaded plants, LUE was $4.36 \mathrm{~g}$ dry mass $\mathrm{MJ}^{-1}$ of PAR, 1.84 times higher than on control plants. This difference was higher than that reported by Cockshull et al (1992). In an experiment with shading plants, these authors calculated values of LUE of 2.65 and $2.88 \mathrm{~g}$ dry mass $\mathrm{MJ}^{-1}$ of PAR in control and heavy shaded plants, respectively. An hypothesis to explain this discrepancy is the low light intensity of Cockshull's experiment, that varied between about $2.0 \mathrm{MJ} \mathrm{m}^{-2}$ day $^{-1}$ of global radiation from 40 to 95 days after anthesis and about $5.5 \mathrm{MJ} \mathrm{m}^{-2}$ day $^{-1}$ afterwards. In the present experiment, average values were $12.4 \mathrm{MJ} \mathrm{m}^{-2}$ day $^{-1}$ and $5.0 \mathrm{MJ} \mathrm{m}^{-2}$ day $^{-1}$ in control and shaded plants, respectively. These results reinforce the hypothesis pointed out above, that radiation levels may have been excessive and may have affected negatively the growth of control plants. Although air temperatures were not measured, it may be hypothesised that daily patterns of this variable were lower in shaded plants, and this factor may also contribute to higher rates of photosynthesis and dry mass accumulation. This hypothesis is supported by the dynamics of SLA (Figure $3 b)$, showing shaded leaves were more expanded, a factor that could increase light absorption by the crop canopy at low values of LAI.

The daily average solar radiation of $5.0 \mathrm{MJ} \mathrm{m}^{-2}$ day $^{-1}$ incident on shaded plants was below the trophic limit of $8.4 \mathrm{MJ} \mathrm{m}^{-2}$ day $^{-1}$. This implies that this limit could not be taken on a world-wide scale. Probably, other climatic variables as day and night air temperatures play an essential role in determining potential crop growth under limiting climatic conditions. For establishing the climatic suitability of horticultural crops in different regions, it should be advisable to take into account also other variables than solar radiation.

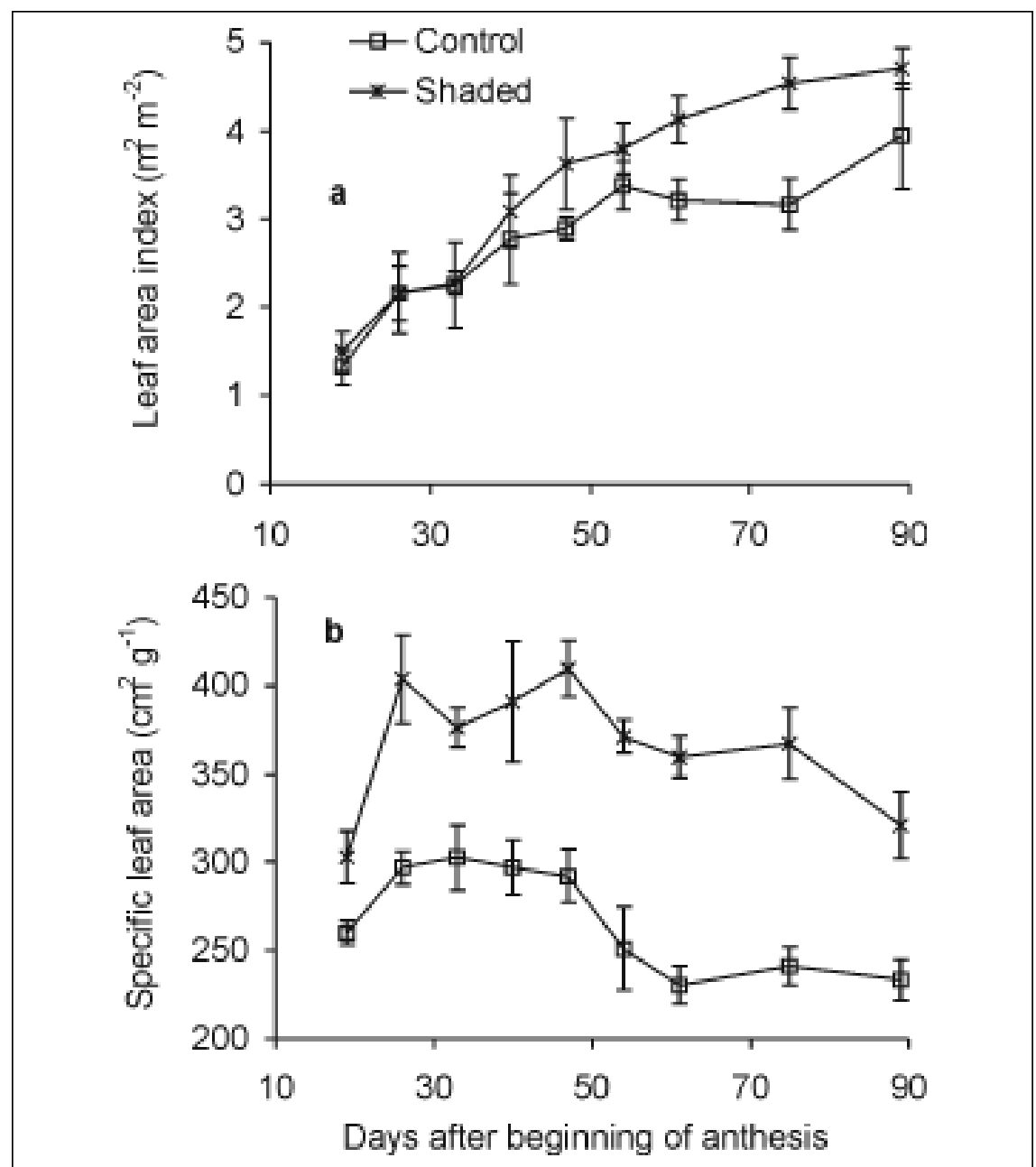

Figure 3. Leaf area index (a) and specific leaf area (b) of control and shaded greenhouse tomato plants during the growing period. Santa Maria, UFSM, 2000.

\section{CITED LITERATURE}

ANDRIOLO, J.L.A.; STRECK, N.A.; BURIOL, G.A.; LUDKE, L.; DUARTE, T.S. Growth, development and dry matter distribution of a tomato crop as affected by environment. Journal of Horticulture Science \& Biotechnology, v. 73, p. 125-130, 1998.

BERTIN, N. Environnement climatique, competition pour les assimilats et modélisation de la nouaison de la tomate en culture sous serre. 1993. 120p. Thèse (Doctorat), Institut National Agronomique Paris-Grignon, Paris.

BURIOL, G.A.; ESTEFANEL, V.; ANDRIOLO, J.L.; MATZENAUER, R.; TAZZO, I.F. Disponibilidade de radiação solar para o cultivo do tomateiro durante o inverno no estado do Rio Grande do Sul. Pesquisa Agropecuária Gaúcha. v. 6, n. 1, p. 113-120, 2000.

CHALLA, H.; BAKKER, J. Potential production within the greenhouse environment. In: $\mathrm{ENOCH}$ Z.; STANHILL, G., (Eds.) Ecosystems of the world. The greenhouse ecosystem. Amsterdan: Elsevier, 1998. p. 333-348.

COCKSHULL, K.E.; GRAVES, C.J.; CAVE, C.R.J. The influence of shading on yield of glasshouse tomatoes. Journal of Horticultural Science, v. 67, p. 11-24, 1992.
CTIFL, Centre Technique Interprofessionel des Fruits e des Légumes. Maîtrise de la conduite climatique. Paris: CTIFL, 1995. 127 p.

ESTEFANEL, V.; SCHNEIDER, F.M.; BERLATO M.A. Insolação e radiação solar na região de Santa Maria, RS: I. Estimativa da radiação solar global incidente a partir dos dados de insolação. Ciência Rural, Santa Maria, v. 20, p. 203-218, 1990.

ESTEFANEL. V.; BURIOL, G.A.; ANDRIOLO, J.L. Disponibilidade de radiação solar nos meses de inverno para o cultivo do tomateiro (Lycopersicon esculentum Mill.) na região de Santa Maria. Ciência Rural, Santa Maria, v. 28, n. 4, p. 553-559, 1998.

FAO. Protected cultivation in the Mediterranean climate. Rome: FAO, 1990. 313 p. (FAO Plant Production and Protection Paper, 90).

HEUVELINK, E. Tomato growth and yield: quantitative analysis and synthesis. 1996. 326 p.

Dissertation, Wageningen Agricultural University, Wageningen.

KONING, A.N.M. Development and dry matter distribution in glasshouse tomato: a quantitative approach. 1994. 240 p. Dissertation, Wageningen Agricultural University, Wageningen.

LAPUERTA, J.C. Anatomia y fisiologia de la planta. In: NUEZ, F., (Coord.) El cultivo del tomate. Madrid: Mundi-Prensa, 1995. p. 43-91. 